\title{
SELF-ASSEMBLY OF A BIOMEMS SYLLABUS: TEACHING BIOMEMS THROUGH THE DEVELOPING ORGANISM
}

\author{
Michel M. Maharbiz \\ Center for Wireless Integrated MicroSystems (WIMS) \\ Electrical Engineering and Computer Science, University of Michigan \\ Ann Arbor, MI, 48109-2122, U.S.A.
}

\begin{abstract}
This paper presents the course philosophy, syllabus, notes, and course feedback on a 'first-run' bioMEMS course offered at the University of Michigan EECS Department (EECS 598: bioMEMS through the developing organism) during Fall 2004. As a teaching experiment, the course explored the use of the natural hierarchy of biological organization to structure the bioMEMS material. The syllabus took a bottom-up path from gene, to protein, metabolism, signaling, tissues, and finally, to organism. Each section emphasized the engineering community's search for revolutionary technologies at that interface. The course was designed for students who had already taken the Introduction to MEMS course at the University of Michigan (EECS 414).
\end{abstract}

\section{INTRODUCTION}

As an emerging field, bioMEMS is often ill-defined; this makes it particularly difficult to parse and organize into a coherent system for teaching. Moreover, it is a field which, by definition, exists precisely at the interfaces between disciplines. How should a bioMEMS course be structured? How is the organization relevant to the research needs of the students and the community?

The standard organization of bioMEMS courses tends to fall into one of two categories: 1) by technological subdomain (e.g., 1 week on microfluidics, 2 weeks on solid-state chemical sensors, etc.) or 2) by application (e.g., implantable clinical devices, nonimplantable point-of-care clinical devices, basic biomedical research, etc.). This paper presents the results of teaching bioMEMS through a different, third approach: bioMEMS through the biology of the developing organism.

The course uses the hierarchy of biological organization to motivate microtechnology instruction. By beginning with genes and hierarchically working upwards, students learn about both the biological problems and the technologies used to tackle these problems. This approach, moreover, focuses attention on the application space and allows for comparative evaluation of the usefulness of the microtechnologies presented (i.e., the need for miniaturization, or cost reduction, or scaling effects as technology drivers become apparent).

The course is modular: each module begins with a set of lectures on the underlying biology, followed by a review of fundamental physical science or engineering concepts employed in the technology. Figure 1 demonstrates the sequence of topics covered. The microtechnologies applicable to the module are then learned through two or three sessions of intensive paper reviews. The goal is for the revolutionary impact of these technologies to be obvious once the underlying biological concern is understood. The class concludes with groups of two or three students writing sample grant proposals to the NSF or the NIH (using, for example, the NIH R21 format).

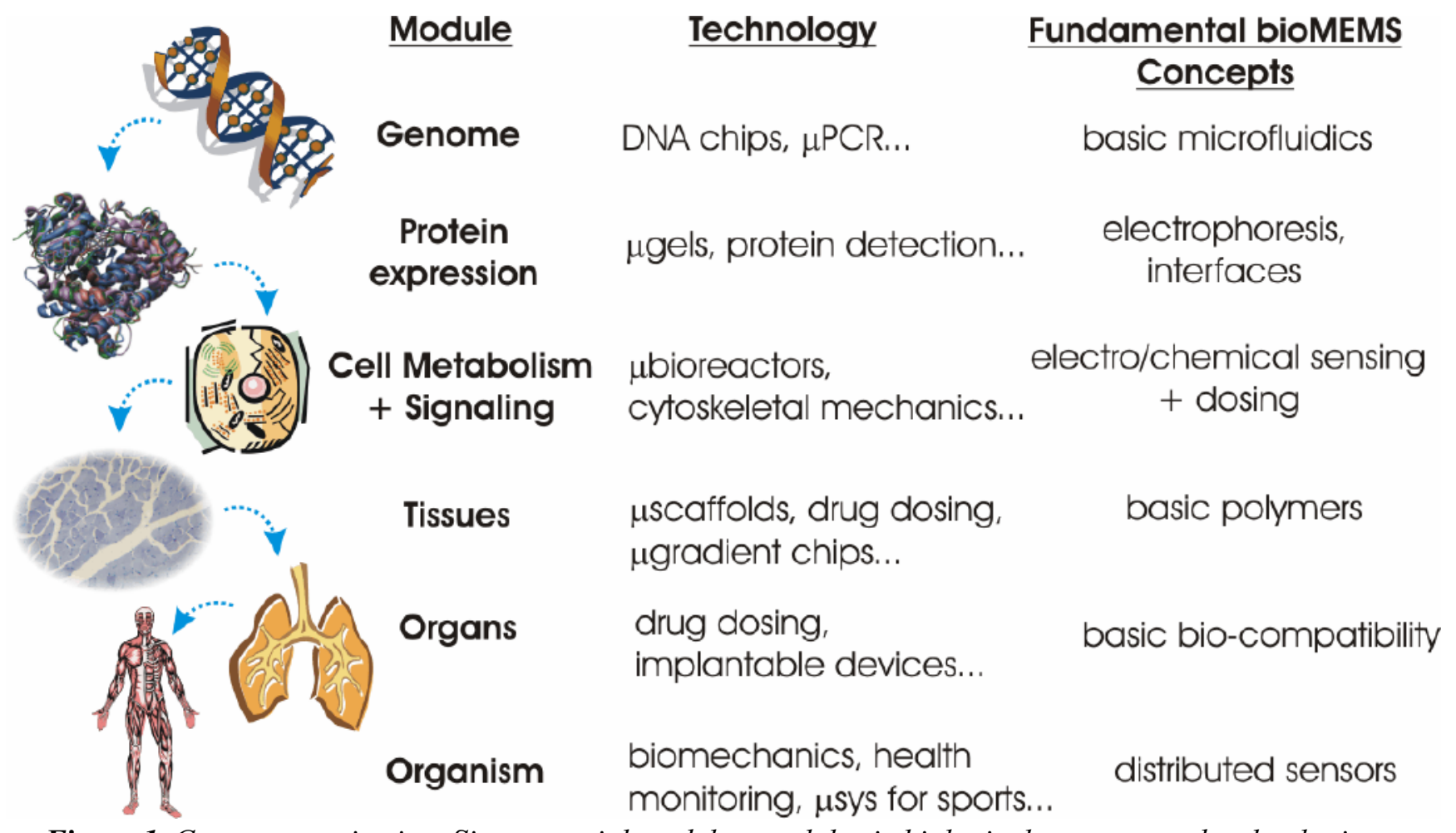

Figure 1. Course organization. Six sequential modules teach basic biological concepts and technologies. 


\section{COURSE OFFERINGS AND ENROLLMENT}

The information presented here is based on a first-run course offered during Fall 2004 (EECS 598: bioMEMS through the developing organism). Total enrollment was 15 , including 3 audits. Of those enrolled, 14 were graduate students and one was an undergraduate. The approach received substantial positive feedback (rated 4.7 / 5.0 by students; college average is 4.21 for 500-level courses). Most students benefited greatly from being forced to properly parse their interests into coherent research directions. This course will be offered as part of the core MEMS curriculum at UM starting Winter 2006 as EECS 516.

\section{COURSE OBJECTIVES}

The course is targeted at advanced undergraduates and first-year graduate students needing an introduction to the interface between microtechnologies and biomedical research. As such, it is assumed that students are at least topically familiar with conventional silicon microtechnologies and microfabrication techniques with EECS 414 as the prerequisite.

The course has three objectives:

1) Familiarize the student with cutting edge microtechnologies in biomedical research.

2) Teach non-bioengineering students the 'language' used by biomedical researchers. In this context, traditional biology methods are described alongside the relevant microtechnologies so as to familiarize students with biomedical method and jargon.

3) Teach students the 'big questions' being asked in biology and medicine.

4) Lastly, the course is designed to provide MEMS students with a direct path into in-depth courses in specific areas (e.g. ,advanced microfluidics in the $\mathrm{ME}$ and $\mathrm{BME}$ departments, tissue engineering course in BME, etc.).

\section{SYLLABUS}

Table 1 lists the topics covered under each module. As of this writing, the class employs the instructor's notes in lieu of a textbook. The following textbooks are provided as reference material:

- MEMS: Senturia [1]

- Biochemistry: Lehninger [2]

- Methods: Klipp [3]
(Klipp deserves special mention as it provides several outstanding introductions to biology, methodology, and mathematics intended for non-biology engineers.)

The first lecture in a module is devoted to the underlying biological principles and language. It is, of course, limited in depth, but the goal is simply to provide a springboard to further digging by the students. The relevant biology or biomedical journals in that subfield are given at the end of the first lecture so that students know where to start their own investigations.

The goal in the second lecture is to describe existing technology not normally seen by microtechnologists. This categorization is not a question of scale or technology-type, but simply reflects the fact that workers in given sub-fields have developed 'gold standards' or 'best practices' that must be understood before microtechnologists can make an impact.

An example may be helpful. If one considers the vast realm of genetic sequencing, no intelligent discussion of microsystems for DNA sequencing can be had before students understand basic PCR, gels, high-throughout methods (such as pyrosequencing), etc. Once this is in hand, intelligent directions in miniaturization can be discerned (miniaturization of sample handling, higher throughput thermal cycling through scaling, the drive towards the $\$ 1 \mathrm{k}$ genome, etc.).

The third lecture is then an overview of the cutting edge microtechnologies in the field. This lecture serves as a guide and an introduction to concepts present in the critical reading. Following the third lecture, two or three sessions are devoted to critical reading and discussion of papers. Reading lists are distributed prior to the beginning of each module. Students are given a single sheet that explains how to read a paper critically; some example statements from that sheet are provided below:

- Papers should be read three times: once for familiarization, once for comprehension and the third for critique. REM sleep is encouraged between reads.

- Distrust the paper from the beginning: e.g. does Eq. 5 really follow from Eq. 4 ?

- There are differences and then there are statistically significant differences between data points or runs. Examine data as though your own.

- Evaluate novelty and proposed use harshly. Just because it's neat or cool doesn't mean it's useful (although I love cool papers!).

- Extrapolate! By the time a paper is published, the work is anywhere from $6-24$ months old! Where do you see this topic going next?

Below is an example of the types of papers read. The following

\begin{tabular}{|c|c|c|c|c|c|c|}
\hline Module & Genes & Proteins & Signaling & Tissue & Organs & Organism \\
\hline Lecture 1 & $\begin{array}{l}\text {-DNA basics } \\
\text {-transcription } \\
\text {-hybridization } \\
\text {-methylation }\end{array}$ & $\begin{array}{l}\text {-protein basics } \\
\text {-translation }\end{array}$ & $\begin{array}{l}\text {-cell-cell signaling } \\
\text {-mechano- } \\
\text { transduction } \\
\text {-morphogens }\end{array}$ & $\begin{array}{l}\text {-tissue org. } \\
\text {-stem cells } \\
\text {-biocompatability }\end{array}$ & $\begin{array}{l}\text { - devbio intro } \\
\text { - body plans }\end{array}$ & $\begin{array}{l}\text {-biomechanics of } \\
\text { locomotion } \\
\text {-health monitoring }\end{array}$ \\
\hline Lecture 2 & $\begin{array}{l}\text {-genome } \\
\text {-promoters, } \\
\text { consensus } \\
\text {-DNA basics }\end{array}$ & $\begin{array}{l}\text {-hydrophobicity } \\
\text {-trans-membr. } \\
\text { proteins } \\
\text {-micro patterned } \\
\text { protein layers }\end{array}$ & $\begin{array}{l}\text {-Dunn chambers } \\
\text {-Boyden chambers } \\
\text {-gels, probes, beads } \\
\text {-optical tweezers }\end{array}$ & $\begin{array}{l}\text {-tissue constructs } \\
\text {-tissue scaffolds }\end{array}$ & $\begin{array}{l}\text { - bio-telemetry } \\
\text {-pacemakers } \\
\text {-stents } \\
\text {-vascular } \\
\text { sensors }\end{array}$ & $\begin{array}{l}\text {-sports sensors } \\
\text {-sensor webs for } \\
\text { the elderly }\end{array}$ \\
\hline Lecture 3 & $\begin{array}{l}\text { - } \mu \text { fluidics } \\
\text {-Navier-Stokes } \\
\text {-laminar flow } \\
\text {-pumping } \\
\text {-valving }\end{array}$ & $\begin{array}{l}\text {-electrophor. } \\
\text {-synthetic protein } \\
\text { assembly } \\
\text {-protein } \mu \text { sensors }\end{array}$ & $\begin{array}{l}\text {-microgradient } \\
\text { generators } \\
\text { - }- \text { mech. sensors and } \\
\text { actuators } \\
\text {-chemical sensing } \\
\text {-microbioreactors } \\
\text {-single cell assays }\end{array}$ & $\begin{array}{l}\text {-tissue } \mu \text { fluidics } \\
\text {-micro patterns + } \\
\text { surfaces }\end{array}$ & $\begin{array}{l}\text {-nano drug } \\
\text { dosing } \\
\text {-implantable } \\
\text { systems and } \\
\text { devices }\end{array}$ & $\begin{array}{l}\text {-distributed sensor } \\
\text { networks } \\
\text {-integrated } \\
\text { complex systems } \\
\text { for biology }\end{array}$ \\
\hline
\end{tabular}

Table 1. Summary of topics covered in the course. Lecture notes available upon request. 
reference list was given to students during lecture 1 of Module 1 and discussed in sessions $4-7$. A complete list for all modules is available by request (although no longer current).

(Sessions 4 - 7) $\quad(\bullet$ mandatory, $>$ recommended $)$ Electrochemical detection (Session 4)

- REVIEW Kerman, K., Kobayashi, M., Tamiya, E. "Recent trends in electrochemical DNA biosensor technology," Meas Sci Technol, vol 15, 2004, R1 R11.

$>$ Robert M. Umek, Sharon W. Lin, Jost Vielmetter, Robert H. Terbrueggen, Bruce Irvine, C. J. Yu, Jon Faiz Kayyem, Handy Yowanto, Gary F. Blackburn, Daniel H. Farkas, and Yin-Peng Chen, "Electronic Detection of Nucleic Acids: A Versatile Platform for Molecular Diagnostics," Journal of Molecular Diagnostics, Vol. 3, No. 2, May 2001, pp. 74-84.

\section{Pyrosequencing (Session 5 - 6)}

- Ronaghi, M., "High-throughput pyrosequencing for analysis of single-nucleotide polymorphisms," Proceedings of the SPIE - The International Society for Optical Engineering, v 4626, 2002, p 316-21

$>$ H. Andersson, W. van der Wijngaart, G. Stemme, Micromachined filter-chamber array with passive valves for biochemical assays on beads, Electrophoresis, vol 22 2001, pp. 249-257.

Nanopore sequencing (Session 6 - 7)

- Meller A, Branton D., "Single molecule measurements of DNA transport through a nanopore," Electrophoresis, vol 16, Aug;23, 2000, pp. 2583-91.

- Jiali Li. Stein, D., McMullan, C., Branton, D., Aziz, M.J., Golovchenko, J.A.," Ion-beam sculpting at nanometre length scales," Nature, v 412, n 6843, 12 July 2001, p 166-9.

- Branton, D., "Nanopore transducers: Prospects for Single Molecule Electrophoresis," The $12^{\text {th }}$ International Conference on solid-state Sensors, Actuators and Microsystems, Boston, MA, June 8-12, 2003, pp. 210-213.

The papers are usually intended to cover a few areas in depth and the author usually played them against each other to elicit contention and heated debate (i.e. "who will win the highthroughput genome race: pyro-sequencing or nanopore sequencing?"). One review paper was used in almost all modules for breadth.

Lastly, for each module, students should be required to provide a one page technical summary (with figure references) for one reviewed paper of their choice (another way to describe this assignment is to have them generate a 'Hilton Head abstract' for the reviewed paper of their choice).

\section{IN-CLASS TECHNICAL DEBATE}

During two modules in the Fall 2004 offering, (chemical sensors and microsystems for force sensing in cell culture), students were divided into three groups of 4 and asked to give 20 minute slide presentations forcefully defending a particular technology. All groups were given competitive technologies so as to elicit debate and heated questions. While this took significant preparation on the part of instructor and students, it appeared to make a significant difference in comprehension.
For example, the chemical sensor debate asked one group to present data on sensing metabolic products with microfabricated amperometric sensors, another group defended microfabricated fluorescent sensors and a third focused on potentiometric techniques.

\section{FINAL PROJECT}

The final deliverable for the class is an NSF or NIH-style proposal. Students are encouraged to form groups of 2 or 3. Halfway through the semester, the author gives them the links to the NIH r21 guidelines and the NSF Proposal Guide. Students then schedule 20 minute meetings as a group with the instructor over the next three weeks so that they can pitch and refine their initial ideas. Five weeks before the end of final exams, each group submitted a one page summary following the standard NSF or NIH format. The instructor graded these, added hand-written notes and performed appropriate course-correction. (Budgets were, of course, completely ignored). The final deliverable was a 15 page proposal description complete with summary, figures and references.

\section{GRADING}

In its original form, class grade is based $30 \%$ on critical review participation, $30 \%$ on the one-page summaries provided after each module, and $40 \%$ on the final proposal project. The next version (offered Fall 2006) will also include 3 homework assignments and a midterm (but no final) based primarily on lecture material to test for more quantitative assessment.

\section{CONCLUSIONS}

Overall, this method for organizing the material was immensely successful. Student feedback (end-of-course surveys and verbal feedback to instructor) indicated overwhelmingly that the class filled a much sought-after need: it allowed them to understand where MEMS could make an impact in the vast spectrum of biomedical research. This, coupled with the use of the course as an intro to further biomedical engineering classes, was perhaps the primary contribution to the curriculum.

The continuing struggle of a class such as this is to provide and test for depth of understanding as well as breadth of topic. While the paper reviews certainly provide depth to some extent, homework assignments and a midterm examination are obviously necessary.

\section{REFERENCES}

[1] S.D. Senturia, Microsystem Design, Kluwer Academic Publishers, 2000.

[2] A. L. Lehninger, Lehninger principles of biochemistry, New York : W.H. Freeman, 4th ed., eds: David L. Nelson, Michael M. Cox., 2005.

[3] E. Klipp, R. Herwig,A. Kowald, C. Wierling, H. Lehrach, Systems Biology in Practice: Concepts, Implementation and Application, Wiley-VCH, Weinheim, 2005. 